\title{
С.Н. Попов
}

\section{ПРАКТИКА РЕАЛИЗАЦИИ КОНСТИТУЦИОННОГО ПРАВА НА ЖИЛИЩЕ ЛИЦ, ОСТАВШИХСЯ БЕЗ ПОПЕЧЕНИЯ РОДИТЕЛЕЙ: НА ПРИМЕРЕ ТЮМЕНСКОЙ ОБЛАСТИ}

\begin{abstract}
Статья посвящена конституционному праву на жилище детей-сирот. Рассмотрена система правового регулирования конституционного права на жилище детей-сирот на примере Тюменской области. Определена проблема отсутствия четкого разграничения полномочий Российской Федерации и субъектов Российской Федерации по обеспечению жильем детей-сирот и установлено, что снижение бюджетной составляющей субъекта Российской Федераџии приводит к уменьшению финансирования из областного бюджета на обеспечение жильем детей-сирот.

Ключевые слова: дети-сироты, дети, лишенные родительской опеки, конституционное право на жилище, обеспечение жильем детей-сирот в Тюменской области.
\end{abstract}

Рассматривать вопрос о детях-сиротах и лиц, которые остались без родительского попечительства, всегда довольно сложно, поскольку судьба этих людей дала им такие тяжелые испытания, как правило, с рождения. Для того чтобы защитить данную категорию населения, необходима система законодательных мер, которая могла бы максимально облегчить долю ребенка, оставшегося без родительского попечения.

Одним из основных элементов защиты является предоставление жилья [1. С. 220]. Актуальность данного вопроса не снижается уже много лет. Ориентация на демократические принципы предусматривает максимальную заботу государства о его жителях. При этом в первую очередь такая помощь должна быть направлена на тех, кто нуждается в ней. Обеспечение ребенка жильем - одна из передовых задач современного общества.

Начиная с 2011 г. более чем в 5,6 раза по сравнению с 2010 г. и более чем в 12 раз по сравнению с 2007 г. увеличился объем средств федерального бюджета, ежегодно предоставляемых в виде субсидий бюджетам субъектов Российской Федерации на обеспечение жильем детей-сирот (2007 г. 0,5 млрд руб., 2010 г. - 1 105,38 млрд руб., 2011-2014 гг. - 6 222,9 млрд руб.) [2. C. 59].

Несмотря на ряд позитивных тенденций, которые стали заметны благодаря комплексу мер высших органов государственной власти, направленных на решение жилищных проблем детей-сирот и детей, оставшихся без попечения родителей, ситуация с обеспечением жильем указанной категории продолжает оставаться крайне сложной, о чем свидетельствуют статистические данные.

Общее количество детей-сирот в возрасте до 18 лет, имеющих право на получение мер социальной поддержки за счет средств бюджета субъектов Российской Федерации с 2011 по 2014 г., увеличилось с 297 до 343 тыс. 
По Уральскому федеральному округу за указанный период времени количество детей-сирот, наоборот, сократилось на 5 тыс. человек (с 46 до 41 тыс.). В Тюменской области (вместе с Ханты-Мансийским автономным округом - Югрой и Ямало-Ненецким автономным округом) также наблюдается положительная тенденция по сокращению количества нуждающихся данной категории лиц на 3 тыс. (с 16 до 13 тыс.) [3].

В соответствии со ст. 40 Основного закона нашего государства каждый имеет право на жилище. Малоимущим, иным указанным в законе гражданам, нуждающимся в жилище, оно предоставляется бесплатно или за доступную плату из государственных, муниципальных и других жилищных фондов в соответствии с установленными законом нормами [4].

Как видим, закон, который имеет наивысшую юридическую силу, направлен на защиту жилищных прав граждан. Конституция Российской Федерации является базисом, в котором закреплен основной принцип обеспечения жильем социально незащищенных слоев населения. При этом вопрос о положении статуса детей-сирот и их права на жилье расширяется рядом региональных нормативно-правовых актов.

До 2013 г. жилье детям-сиротам и детям, оставшимся без родительского попечения, предоставлялось вне очереди. Но такое положение вещей довольно часто становилось проблемным, и его результатом был отказ государственных органов в использовании такой возможности. Уполномоченные лица ссылались на то, что предоставление жилища имеет определенную последовательность в соответствии со специальными реестрами нуждающихся в улучшении условий проживания.

С 2013 г. было принято решение о внесении определенных изменений. Так, жилье данной категории теперь предоставляется на основе договора найма специализированного жилого помещения. Такое изменение в определенной форме снизило конфликтность ситуации.

Рассмотрим существующий порядок обеспечения конституционного права на жилище на примере Тюменской области. В данном субъекте Российской Федерации вопросами составления списка нуждающихся детей занимается департамент социального развития Тюменской области.

В Тюменской области существует ряд нормативно-правовых актов, посвященных вопросам обеспечения детей-сирот. Одним из центральных является Закон Тюменской области от 28.12.2004 № 331 «О социальной поддержке отдельных категорий граждан в Тюменской области» [5]. Однако в нем не рассматривается вопрос об обеспечении жильем, а указываются особенности финансовой поддержки.

Региональным актом, закрепляющим положение о предоставлении жилья, является Закон Тюменской области от 07.10.1999 № 137 «О порядке учета граждан, нуждающихся в жилых помещениях, предоставляемых им по договорам социального найма, и предоставления жилых помещений в Тюменской области» [6]. Он повторяет положения федерального законодательства в данной области, устанавливает органы, которые занимаются вопросом ведения реестра, и порядок предоставления жилища.

До 2008 г. Тюменская область входила в пятерку регионов России, которые имели наивысший показатель среди предоставления жилья детям, ли- 
шенным родительской опеки. После того как этот вопрос передался в местное финансирование, ситуация изменилась. Проблемой Тюменской области сегодня становится недостаточность финансирования. В 2015 г. поступления в бюджет были сокращены. Это вызвало опасения по отношению к финансовому вопросу предоставления жилья детям-сиротам. Суммы из бюджета, которые выделяются на предоставление жилья детям-сиротам в Тюменской области, сегодня значительно ниже, чем, к примеру, в соседних Челябинской и Свердловской областях, где для решения таких проблем выделяется по миллиарду рублей в год.

В 2014 г. для решения жилищного вопроса было выделено 492 млн руб. из областного бюджета [7], а в 2015 г. эта сумма сократилась до 287 млн [8]. По оценке специалистов, такой бюджет позволит приобрести более трехсот жилых помещений. Но для того количества нуждающихся, которые стоят в очереди, его недостаточно.

В настоящее время большинство субъектов Российской Федерации являются дотационными и нуждаются в дополнительных средствах для решения проблем обеспечения жильём социально незащищенных слоев населения.

Это связано с тем, что в Российской Федерации законодательно закреплён определенный порядок конституционного регулирования бюджетных отношений между Федерацией и ее субъектами.

Все полномочия по вопросам установления основных источников налогов, применяемых в субъектах Российской Федерации и муниципальных образованиях, принадлежит Российской Федерации. Её субъекты и муниципальные образования реализуют ограниченную налоговую компетенцию по введению и определению регионального или местного налога на своей территории [9. С. 37]. Распределение расходных обязательств, в частности по обеспечению жильем детей-сирот, неразрывно связано с закрепленными за соответствующим уровнем публичной власти расходными полномочиями.

Федеральным законом от 06.10.1999 № 184-Ф3 «Об общих принципах организации законодательных (представительных) и исполнительных органов государственной власти субъектов Российской Федерации» [10] (далее - Федеральный закон № 184-Ф3) установлен исчерпывающий перечень полномочий органов государственной власти субъектов Российской Федерации по предметам совместного ведения, которые финансируются за счет собственных доходов субъектов Российской Федерации.

В частности, пп. 14.2 п. 2 ст. 26.3 Федерального закона № 184-Ф3 установлено полномочие по финансированию обеспечения детей-сирот и детей, оставшихся без попечения родителей, лиц из числа детей-сирот и детей, оставшихся без попечения родителей, жилыми помещениями.

Проблема заключается в том, что до сих пор не удается в вопросах совместного ведения Федерации и ее субъектов надлежащим образом осуществить полноценное распределение полномочий по обеспечению жильем социально незащищенных слоев населения. Формулировки, содержащиеся в законодательстве, в частности в названном перечне, не позволяют однозначно определить надлежащего обладателя полномочий по обеспечению жильем социально незащищенных слоев населения. 
В ст. 40 Конституции Российской Федерации установлено право на жилище малоимущих и иных указанных в законе граждан. Поскольку Конституция Российской Федерации является Основным законом Российской Федерации, то обеспечение по реализации указанного права должно принадлежать государству.

Не случайно в 2013 г. в ст. 26.3-1 Федерального закона № 184-Ф3 внесено изменение, согласно которому органы государственной власти получают право устанавливать за счет средств регионального бюджета дополнительные меры социальной поддержки и социальной помощи для отдельных категорий граждан вне зависимости от наличия в федеральных законах положений, регулирующих указанное право. Финансирование таких полномочий является правом, а не обязанностью субъекта Российской Федерации, не влечет выделения дополнительных средств из федерального бюджета и ограничивается собственными финансовыми возможностями [11].

Подводя итоги нашего исследования, необходимо указать, что право на жилище является неотъемлемым правом человека. При этом, учитывая положения Конституции Российской Федерации (ч. 3 ст. 40), полномочия по обеспечению жильем детей-сирот и детей, оставшихся без попечения родителей, должны относиться к Российской Федерации.

Возможность возложения данной обязанности на субъект Российской Федерации обусловливает две проблемы. Первая проблема заключается в том, что в настоящее время отсутствует четкое разграничение полномочий Российской Федерации и субъектов Российской Федерации по обеспечению жильем социально незащищенных слоев населения.

Второй проблемой является резкое снижение бюджетной составляющей субъекта Российской Федерации, в результате чего возникает недостаточность финансирования из областного бюджета на обеспечение жильем детей-сирот и детей, оставшихся без попечения родителей. Та сумма, которая предусмотрена для решения вопроса обеспечением жильем, не сможет решить проблему полностью. Согласно положениям Федерального закона № 184-Ф3 финансирование таких полномочий является правом, а не обязанностью субъекта Российской Федерации и ограничивается собственными финансовыми возможностями. И соответственно вопросы, связанные с финансированием обеспечения жильем детей-сирот, должны принадлежать Российской Федерации.

\section{Лuтература}

1. Всеобщая декларация прав человека. Принята 10 дек. 1948 г. Резолюцией 217А Генеральной Ассамблеи ООН // Действующее международное право: в 2 т. Т. 2 / сост. Ю.М. Колосов, Э.С. Кривчикова. М.: Междунар. отношения, 2007. С. 218-223.

2. Аналитический вестник Совета Федерации РФ. (2013) № 3 (487): Соблюдение и защита прав, свобод и законных интересов ребенка: «Россия без сирот» [Электронный ресурс] // Бюджетная система РФ. URL: http://www.budgetrf.ru/Publicatio№s/ MagaziNoes/Vest№ikSF/2013/ 3_487/VSF_№EW_3_487.pdf (дата обращения: 25.11.2015).

3. Семья, материнство и детство. П. 4.5: Численность детей-сирот и детей, оставшихся без попечения родителей, в возрасте до 18 лет, имеющих право на получение мер социальной поддержки за счет средств бюджета субъекта РФ) [Электронный ресурс] / Федеральная служба государственной статистики. URL: http://www.gks.ru/wps/wcm/co№oect/rosstat_mai№/ rosstat/ru/ statistics/populatio№/motherhood/\# (дата обращения: 25.11.2015). 
4. Конституциия Российской Федерации. Принята всенародным голосованием 12.12.1993: по сост. на 21.07.2014 // Собрание законодательства РФ. 2014. № 31. Ст. 4398.

5. О социальной поддержке отдельных категорий граждан в Тюменской области: Закон Тюменской области от 28.12.2004 № 331: по сост. на 07.05.2015 // Вестник Тюменской областной думы. 2004. № 15, ч. 1.

6. O порядке учета граждан, нуждающихся в жилых помещениях, предоставляемых им по договорам социального найма, и предоставления жилых помещений в Тюменской области: Закон Тюменской области от 07.10.1999 № 137: по сост. на 13.10.2015 // Вестник Тюменской областной думы. 1999. № 9.

7. Об областном бюджете на 2014 год и на плановый период 2015 и 2016 годов: Закон Тюменской области от 01.11.2013 № 87: по сост. на 18.12.2014 // Вестник Тюменской областной думы. 2013. № 9.

8. Об областном бюджете на 2015 год и на плановый период 2016 и 2017 годов: Закон Тюменской области от 02.12.2014 № 115: по сост. на 29.09.2015 // Вестник Тюменской областной думы. 2014. № 12 .

9.Шевелева Н.А. Бюджетное выравнивание в России как способ гармонизации межбюджетных отношений (2000-2015) // Сравнительное конституционное обозрение. 2015. № 2. C. $32-44$.

10. Об общих принципах организации законодательных (представительных) и исполнительных органов государственной власти субъектов Российской Федерации: Федеральный закон от 06.10.1999 № 184-ФЗ: по сост. на 03.11.2015 // Собрание законодательства РФ. 1999. № 42. Ст. 5005.

11. О внесении изменений в статьи 26.3 и 26.3-1 Федерального закона «Об общих принципах организации законодательных (представительных) и исполнительных органов государственной власти субъектов Российской Федерации»: Федеральный закон от 21.12.2013 № 371-Ф3: по сост. на 01.01.2014 // Собрание законодательства РФ. 2013. № 51. Ст. 6691.

Popov Sergey N. Tyumen state University (Tyumen, Russian Federation)

PRACTICE OF REALIZATION OF THE CONSTITUTIONAL RIGHT TO HOUSING OF PERSONS WITHOUT PARENTAL SUPPORT: ON THE EXAMPLE OF THE TYUMEN REGION

Keywords: orphan children; the children deprived of parental guardianship; constitutional right to housing; provision of housing for orphan children in the Tyumen region.

One of the basic elements of protection of orphan children and persons without parental guardianship is provision of housing. The topicality of the matter is not decreasing during many years. With regard to the above, such protection has to be directed to those who need it. To provide the child with a roof over his head is one of the foremost tasks of modern society.

Since 2011, the volume of funds of the federal budget, which are annually granted in the form of subsidies to the budgets of subjects of the Russian Federation for providing housing for orphan children, increased.

Despite a number of positive tendencies which became noticeable thanks to a package of measures of the supreme bodies of government directed to the solution of housing problems of orphan children the situation with provision of housing for the specified category continues to remain extremely complicated. This can be proved by the statistical data given in the article.

According to Article 40 of the Constitution of the Russian Federation, everyone has the right to housing. Housing is provided to the poor and other needy citizens either free of charge or for an available payment from the state, municipal and other housing stocks according to the norms established by law.

The law having the highest juridical force is aimed at the protection of housing rights of citizens. At the same time, regional laws and regulations develop the question of the status of orphan children and their right to housing.

The article examines several statutory instruments of the Tyumen region. For example, the Law of the Tyumen region of 28.12.2004 No. 331 "About social support of separate categories of citizens in the Tyumen region" (the law regulates some special aspects of financial support of separate categories of citizens), etc. and deals with a certain order of the constitutional regulation of budgetary relations between the Russian Federation and its subjects. 
The article brings up an issue that it is still impossible to distribute powers holders between the Federation and its subjects in the sphere of providing housing for socially unprotected groups of population duly.

The author comes to some conclusions. Firstly, there is lack of accurate separation of powers between the Russian Federation and the subjects of the Russian Federation in provision of housing for orphan children. Secondly, the decrease of the budget for subjects of the Russian Federation results in reduction of financing of housing for orphan children from regional budgets.

\section{References}

1. Kolosov, Yu.M. \& Krivchikova, E.S. (eds) (2007) Deystvuyushchee mezhdunarodnoe pravo: v 2 t. [Current International Law: In 2 vols]. Vol. 2. Moscow: Mezhdunar. Otnosheniya. pp. 218-223.

2. Budgetrf.ru (2013) Soblyudenie i zashchita prav, svobod i zakonnykh interesov rebenka: "Rossiya bez sirot" [Protection of the rights, freedoms and legitimate interests of the child: "Russia without orphans"]. Analiticheskiy vestnik Soveta Federatsii RF. 3(487). [Online] Available from: http://council.gov.ru/activity/analytics/analytical_bulletins/25942/. (Accessed: 25th November 2015).

3. Federal State Statistics Service. (n.d.) Sem'ya, materinstvo i detstvo. P. 4.5: Chislennost' deteysirot $i$ detey, ostavshikhsya bez popecheniya roditeley, $v$ vozraste do 18 let, imeyushchikh pravo na poluchenie mer sotsial'noy podderzhki za schet sredstv byudzheta sub"ekta RF) [Family, motherhood and childhood. P. 4.5: The number of orphans and children left without parental care, under the age of 18 years, eligible for social support measures from the budget of the subject of the Russian Federation)]. [Online] Available from: http://www.gks.ru/wps/ wcm/co№№ect/ rosstat_maiNo/ rosstat/ru/ statistics/populatio№/motherhood/\#. (Accessed: 25th November 2015).

4. Russian Federation. (2014) Konstitutsiya Rossiyskoy Federatsii. Prinyata vsenarodnym golosovaniem 12.12.1993: po sost. na 21.07.2014 [The Constitution of the Russian Federation. Adopted by popular vote on December 12, 1993: as of July 21, 2014]. Legislative Bulletin of the Russian Federation. 31. Art. 4398.

5. Tyumen Regional Duma. (2015a) O sotsial'noy podderzhke otdel'nykh kategoriy grazhdan v Tyumenskoy oblasti: Zakon Tyumenskoy oblasti ot 28.12.2004 № 331: po sost. na 07.05.2015 [On the social support of certain categories of citizens in Tyumen Region: Law № 331 of Tyumen Region dated by December 28, 2004: as of july 5, 2015]. Vestnik Tyumenskoy oblastnoy dumy. 15(1).

6. Tyumen Regional Duma. (1999) O poryadke ucheta grazhdan, nuzhdayushchikhsya $v$ zhilykh pomeshcheniyakh, predostavlyaemykh im po dogovoram sotsial'nogo nayma, i predostavleniya zhilykh pomeshcheniy v Tyumenskoy oblasti: Zakon Tyumenskoy oblasti ot 07.10.1999 № 137: po sost. na 13.10.2015 [On the procedure for registering citizens in need of accommodation provided to them under social employment contracts and the provision of housing in Tyumen Region: Law No. 137 of Tyumen Region of October 7, 1999: as of October 13, 2015]. Vestnik Tyumenskoy oblastnoy dumy. 9.

7. Tyumen Regional Duma. (2013) Ob oblastnom byudzhete na 2014 godi na planovyy period 2015 i 2016 godov: Zakon Tyumenskoy oblasti ot 01.11.2013 № 87: po sost. na 18.12.2014 [About the regional budget for 2014 for the planning period of 2015 and 2016: Law № 87 of Tyumen region dated by November 1, 2013: as of December 18, 2014]. Vestnik Tyumenskoy oblastnoy dumy. 9.

8. Tyumen Regional Duma. (2014) Ob oblastnom byudzhete na 2015 god i na planovyy period 2016 i 2017 godov: Zakon Tyumenskoy oblasti ot 02.12.2014 № 115: po sost. na 29.09.2015 [On the regional budget for 2015 and for the planning period 2016 and 2017: Law No. 115 of Tyumen region dated December 2, 2014: as of September 29, 2015]. Vestnik Tyumenskoy oblastnoy dumy. 12.

9. Sheveleva, N.A. (2015) Budget system in russia: fiscal equalization as a way of harmonizing inter-budgetary relations (2000-2015). Sravnitel'noe konstitutsionnoe obozrenie - Comparative Constitutional Review. 2. pp. 32-44. (In Russian).

10. Russian Federation. (1999) On the general principles of the organization of legislative (representative) and executive bodies of state power of the subjects of the Russian Federation: Federal Law No. 184-FZ of October 6, 1999: as of November 3, 2015. Legislative Bulletin of the Russian Federation. 42. Art. 5005. (In Russian).

11. Russian Federation. (2013) On amending Articles 26.3 and 26.3-1 of the Federal Law No. 371-FZ, On general principles for the organization of legislative (representative) and executive bodies of state power in the subjects of the Russian Federation. Federal Law of December 21, 2013: as of January 1, 2014. Legislative Bulletin of the Russian Federation. 51. Art. 6691. (In Russian). 